\title{
Assessment of Technological Capabilities of a Production System from a Position of Flexible Risk Management
}

\author{
Ilona I. Drozdova ${ }^{1} \&$ Elena V. Lyapuntsova ${ }^{1}$ \\ 1 Moscow State University of Railway Engineering-MIIT, Moscow, Russia \\ Correspondence: Ilona I. Drozdova, Director of the Centre of Competences and education quality management, \\ Moscow State University of Railway Engineering-MIIT, Obraztsova str., 9 bld.9, Moscow, 127994, Russia. \\ E-mail: ildrozd@yandex.ru
}

Received: December 29, 2014

doi:10.5539/res.v7n4p241

\author{
Accepted: January 22, 2015 Online Published: February 11, 2015 \\ URL: http://dx.doi.org/10.5539/res.v7n4p241
}

\begin{abstract}
Forecasting of technological development of economy in general and its separate branches is one of the most important and most complex problems of long-term forecasting. From a position of technological development of research show that throughout all horizon of forecasting the economy of the Russian Federation is in the mode which is catching up (catch-up). Overcoming of backward technological level of the production device of the Russian economy demands further building not only investment activity, but also labor productivity according to the international standards. The purpose of this work is the analysis of opportunities of flexible development of the adaptable mechanism of a production system in the conditions of unstable environment.
\end{abstract}

Keywords: import substitution, industrial enterprises, competitiveness, production potential, management risk

\section{Introduction}

Now there is an active process of formation of the national and international markets of knowledge. Between the leading countries rivalry for intellectual leadership accrues. The intellectual capital having high education level and cultural traditions, scientific and industrial potential, etc. in the basis becomes the main source of competitive advantages of the countries and the largest companies.

The share of branches of the increased demand for knowledge (high-tech industries, telecommunication communication, financial and business services) in gross domestic product averages $30-35 \%$. This indicator is equal in Russia $11.5-12 \%$. Such branches differ in the highest growth rates of outputs, employment, investments, a foreign trade turnover. In the developed countries of investment into basic researches are considered as the highly effective direction of an expenditure of public funds.

That now investments into knowledge grow in the developed countries quicker, than investments into fixed assets attracts attention.

Control in the holding company is integrated is exercised concerning three types of objects:

- Holding in general, as set of business units;

- Business unit, as set of production facilities;

- Production facility.

Isolation of kinds of activity in business units increases efficiency of activity for the account:

- Managements of a kind of activity as business, i.e. the activity directed on creation of a value added;

- Specializations of business units in kinds of activity;

- Possibilities of an exact assessment of the income, expenses, the involved assets, the capital and efficiency of separate kinds of activity;

- Possibilities of flexible management of a set of business units.

The elementary model constructed by P. Douglas answers the following equation: 
$Y=a K^{a} L^{b}$

$Y$ - production index

$a$ - labor productivity coefficient

$K$ - capital index

$L$ - labor index

$a>0, b>0$

- resource effectiveness

Thus effectiveness ratio of use of work and the capital are connected among themselves by the following expression:

$a+b=1$

The modified equation of Kobba-Douglas has an appearance:

$Y=a e^{l t} K^{a} L^{1-a}$

$l$ - constant of technical progress

From the economic point of view ability of a formula of Kobba is important-Douglas to connect among themselves need for resources of various type. Special size-limit rate of replacement is for this purpose entered (MRS - marginal rate of substitution). From this it follows that both the capital, and volume of labor have to be balanced.

\section{Methodological Framework}

By an assessment, by 2020 the volume of investment into fixed capital has to exceed pre-crisis (2008) level by 1.9-2.1 times, and by 2025 - not less than three times. Only such trajectory will be able to provide minimum necessary quality of the production device and competitive technological level of the majority of sectors of the Russian economy.

For example, the general comparison of the technical means operated on the Russian railway transport with foreign analogs shows essential lag of the Russian equipment according to key characteristics. Achievement of technical and technological parity with the leading countries of the world causes need of innovative break for a domestic transport machine-building complex and allied industries of the industry.

The role of Investments in creation of competitive advantage is not always the same and depends, first of all, on the stage which has been achieved by the country in development of national competitiveness. Therefore stability of competitiveness is often viewed as the change of 3 consecutive stages: factorial, investment and innovative advantages. Here at the stage of innovations the main emphasis is made on high-tech segments of national economies when the key target is not improvement of separate factorial conditions but improvement and renewal of technology. The research performed by World Bank showed that economy of modern Russia is much less diversified then economy of the USSR (WTO Public Forum, 2013). Economic growth which was observed in Russian Federtion after 2000 was based on natural resources, first of all, on oil and gas, and this trend, in specialists' opinion, will remain unchanged in the nearest future. During the last decade annual increment in export of the products of oil and gas sector is continually increasing, and in 2010 its share in total export volume was almost $69 \%$. But if we consider export in the context of all Russian economy we must wary that in spite of economic growth this growth will be restricted to just several industries. And main problem of import substitution is not in creation of new companies but in their low stability in conditions of Russian economy, let alone world economy. In these conditions import will push out the products of national producers from the market, many of them will be obliged to shut down their producing operations. If to analyze the situation which developed in industrial sector of national economy, it is necessary to pay special attention to the following threats: outdated technologies and the equipment, and also a considerable import segment in prime cost of an industrial output. One of options of realization of policy of import substitution in modern Russia is the 
organization of industrial assembly which can hardly be estimated as effective from positions of strengthening of a role of the national producer. So, operation schedule of placement of the capital declared by foreign investors isn't maintained; from 200 Russian firms the status of subsuppliers is had only 42; any plant didn't reach the ordered seriality in 300 thousand cars a year. from all Russian subsuppliers of plastic in a technological chain it is included so far still the foreign partner gets only one, most part of profit. Existence of import accessories is a necessary condition of effective export on the markets of foreign countries as the enterprises at a choice of suppliers are guided by a complex of objective technical and economic parameters of the bought goods. But requirements to quality of production increase over time and, as a result, their prime cost increases. Such succession of events can cause or further increase in prices for production containing import accessories, or curtailment of production of this production, or complete technological (economic) dependence in the remote prospect. There are two main approaches from which positions it is possible to model and analyze interrelation between accumulation of the human capital and economic growth.

The first approach contains in the theory of the human capital of G. Becker. It is based on idea that economic growth is put in action by accumulation of the human capital. According to this approach, distinctions at rates of economic growth of the company arise mostly because of distinctions at rates with which they accumulate the human capital. The second approach earlier also originates in R. Nelson and E. Phelps's work. At this approach it is supposed that the stock of the human capital defines abilities of the developing economy to innovations and/or loan of technologies at more developed countries that, in turn, promotes acceleration of economic growth.

They prove that education and vocational training increase ability to the adaptation and use of new technologies which are continuously realized in economic growth.

$$
\frac{\frac{d A}{d t}}{A}=c(H) \cdot \frac{T_{t}-A_{t}}{A_{t}}
$$

$T_{t}$-theoretical level of knowledge at the time of $\mathrm{t}$ (greatest possible level $A_{t}$ at the time of $\mathrm{t}$ ). It is obvious that growth rate $A$ depends on gap size between theoretically possible and actually reached level $A_{t}$ and functions $C(H)$, depending on the size of the saved-up human capital, and

$$
\frac{d C}{d H}>0
$$

Benhabib and Spiegel developed this model, having presented that filling of a gap between theoretically possible and actually reached level $A_{t}$ happens to the help of loan ("interception") of technologies. According to Benkhabibu and Spiegel, growth rate of parameter of productivity $A$ for i-oh of economic system (branch, the enterprise) it can be written down as follows:

$$
\frac{\frac{d A_{i t}}{d t}}{A_{i t}}=g\left(H_{i}\right)+c\left(H_{i}\right) \frac{A_{i t \max }-A_{i t}}{A_{i t}}
$$

The production rule of decision-making consists in using all capacities for production with application of the current technology. At the set assumptions about behavior cumulative release and cumulative demand for a manpower directly are defined by a condition of branch. T.o., the constant set of technological capabilities is 
given, and each technology is characterized by coefficients of expenses $a_{1}$ and $a_{k}$. Technical progress is carried out as this set is examined and reveals. For any organization occupied with such inspection, search локален in the sense that distribution of probabilities of that is found, concentrated on the technologies close to the current. A distance formula between technologies $h$ and $h_{1}$, where $W T L+W T K=1$, i.e. the average weighed absolute differences of logarithms of coefficients of expenses has an appearance:

$$
D\left(h, h_{1}\right)=W T L\left|\log a_{l}^{h}-\log a_{l}^{h_{1}}\right|+W T K\left|\log a_{k}^{h}-\log a_{k}^{h_{1}}\right|
$$

Thus, it is statistically proved that each unit of the capital during every period independently fails with probability $D=0.04$. The firm accepts the alternative rule revealed in the course of search, only if it promises higher income on capital unit, than the current technology. At any time fixed capital at the used technologies defines the demanded expenses of work and their return. The organizations put the income which remained with them after payment of a salary and the demanded dividends in acquisition of the new capital. Thus, new technologies can enter a set of technologies as a result of emergence of new inventions, or as a result of their loan at the countries with higher technological level of development.

As the level of technological achievements isn't observed directly, G. Badinger and G. Tondl use labor productivity level $Y^{*}$ as the variable characterizing this level. It is noted that process of "interception of technologies" can be specified as follows

$$
\Delta \ln A_{t}=\eta_{1}\left(\frac{Y_{\mathrm{max}, t}^{*}}{Y_{t}^{*}}\right)=\eta_{1} G A P_{t}
$$

$Y_{\text {max, } t}^{*}$-labor productivity level of the technological leader, parameter $\eta_{1}$ characterizes the speed of overcoming of lag from the leader. R. Nelson and E. Phelps proved that interception parameter $\eta_{1}$ is the growing function of the human capital. I. Benkhabib and M. Shpigel defined interception process as follows:

$$
\Delta \ln A_{t}=\eta_{2} \cdot h_{t}\left(\frac{Y_{\max , t}^{*}-Y_{t}^{*}}{Y_{t}^{*}}\right)=\eta_{2} \cdot h_{t} \cdot G A P_{t}
$$

During any period of costs of unit of production are so-so weighed from work costs of release unit at the set technologies. The relative importance of old and new technologies will change as follows:

$$
\frac{d}{d l^{1}} \log \left(\frac{K_{2}}{K_{1}}\right)=\frac{\dot{K_{2}}}{K_{2}}-\frac{\dot{K_{1}}}{K_{1}}=\lambda w\left(l_{1}-l_{2}\right)=\lambda w(1-\alpha) l_{1}
$$

If to consider production function of model of innovative economic growth - three-sector mathematical model of P. Romer taking into account entrance variables, factors of environment and parameters of a condition of the analyzed system, analytically the model can be presented production function

$$
Y\left(H_{Y}, L, x\right)=H_{Y}^{\alpha} L^{\beta} \sum_{i=1}^{\infty}(x)_{1}^{1-\alpha-\beta}
$$

$i$ - the index attributed to each separate type of means of production, 
$x=\left\{\begin{array}{c}\infty \\ x \\ i=1\end{array}\right\}$

- the list of the means of production used by the organizations for release of end products,

$\alpha, \beta$ - some technological parameters.

Thus, change of the general capital of all three-sector system can be defined as

$K(t)=Y(t)-C(t)=\eta \sum_{i=1}^{\infty} x_{i}$

Taking into account investments into the fixed business assets and personnel potential,

$F(K, H, A(t), L)=K^{\alpha} H^{\beta}\left(A e^{j t} L\right)^{1-\alpha-\beta}$

$H$ - function of change of structure of highly professional labor taking into account investments into personnel potential

\section{Results}

The functional structure of a production system includes some subsystems, such as: the technological, serving, providing and scientific and technical preparation. At change of the production technology the analysis of system from a position of investment can be carried out concerning three stages: accumulation, return of accumulation and completion of transition process to the new level of technological use.

The first stage is a stage of accumulation. In these conditions mainly old way of production works. Accumulation happen due to reduction of specific consumption at basic technology to minimum admissible level.

The second stage is a stage of return of accumulation.

$L_{1}(t)=\frac{\left(c_{0}-c_{\min }\right) L_{o}}{k_{1}} \times e^{R}$

The third stage - a stage of completion of transition process $(\tau 2<\mathrm{t}<\mathrm{T})$

$L_{1}(t)=L_{1}\left(\tau_{2}\right) e^{R\left(e^{\gamma t}-e^{\gamma \tau_{2}}\right)+\mu\left(\tau_{2}-t\right)}$

The moment of the end of transition process of $\mathrm{T}$ occurs when a manpower is completely transferred from basic to new technology, and is defined from the equation:

$R\left(e^{\gamma T}-e^{\gamma \tau_{2}}\right)=\ln \left(\frac{L_{0}}{L_{1}\left(\tau_{2}\right)}\right)-\mu\left(\tau_{2}-T\right)$

Efficiency of a unit of labor $A_{t}$ it is described by exogenous process:

$$
\frac{A_{t+1}-A_{t}}{A_{t}}=\beta_{1} \ln \frac{A_{F t}}{A_{t}}+\left(\beta_{2} \frac{G_{R t}}{Y_{t}}+\beta_{3} E_{t}\right) \ln \frac{A_{F t}}{A_{t}}+k_{1} \frac{G_{R t}}{Y_{t}}+k_{2} E_{t}
$$

In model intra-branch turns of shots are more carefully considered (Models, similar models P. of Herbst, can be used for decision-making process modeling by "potential workers". However in a similar case carrying out special inspections of this group is necessary obosnovanny to approach an assessment of parameters of such model). It is possible to make it, for example, by means of models P. of Herbst or J. Kloves which essence is as follows.

P. Herbst came to a conclusion that it is necessary to consider "structure of making decision" on leaving or not 
leaving from the enterprise, and described a labor turn by means of decision-making model.

However still there is sharp a question concerning a formula of localization of production. The state didn't admit a localization assessment technique to branches today yet. As a result of lack of uniform system of measurement, everyone counts localization depth by the technique (customs property, physical and time expenditure, etc.) that doesn't allow to estimate the solutions proposed by producers fully.

The new wave of technological changes which is sharply strengthening a role of innovations in social and economic development and depreciating many traditional factors of growth is expected.

In the next decade the developed countries will pass to formation of the new technological base of economic systems based on use of the latest developments of biotechnologies, informatics and nanotechnologies.

\section{Discussions}

The neoclassical doctrine is based upon an assumption that during any set period there is a wide scale of technological capabilities from which the organization can choose. Respectively, at any time between the organizations there are essential distinctions in the applied technology, productivity and profitability. It is considered that the organization during any period possesses various potential opportunities, procedures and rules of decision-making which define their actions under the set external conditions. During the concrete period of time the organization is characterized by the production technology applied by it which is described by coefficients of expenses and volume of fixed capital.

T. Shults, E. Denison, J. Kendrick, etc. made a quantitative assessment of a contribution of education to economic growth. It was established that for the XX century accumulation of the human capital advanced rates of accumulation of the physical capital.

In world practice the significant contribution to development of the theory of the accounting of the human capital was made by the American scientist Eric Flamkholts. He noted that human resources need to be considered as an asset of the company, and allocated three main criteria of recognition of human resources as asset: potential future benefit, existence of the rights of possession or control from an economic entity, measurability in terms of money.

The gravitational equations (Hanson, 2012, p were widely adopted. 48), appeared the real find for modeling of volumes of trade streams. In them act as the main independent variables the level (size) of GDP of the countries - partners and geographical distance between them, and dependent

variable - export/import volume between the countries.

Secondly, by the end of the 1970th years it became known many facts which weren't keeping within Hekshera-Olin's model (the major role in it was played by a ratio of factors of production). Volumes of intra-branch trade were considerable, and growth of trade streams happened generally between the developed countries similar on a level of development of technologies and security with production factors.

As a result of new models of international trade (such as Helpmana-Krugman's model (Helpman \& Krugman, 1985)) which could explain these facts by means of effect of the increasing return from scale and the monopolistic competition began to appear. A few years ago R. Hausmann and B. Klinger offered the concept of discrete space of products within which it is possible to count the distances from one product to another showing probability of that some country will specialize on export of certain goods (Hausmann \& Klinger, 2006, 2007).

\section{Conclusion}

After the entry of Russia into the World Trade Organization (WTO) most sharply there was a question of competitiveness of a domestic production in comparison with foreign analogs in domestic market of Russia.

Competitiveness of industries is based on competitive advantages which all variety can be reduced to two main types: resource and technological.

In Russia now actually there is no production of a number of accessories without which creation of the equipment corresponding to world level is impossible.

\section{References}

Development strategy of transport machine-manufacturing in Russian Federation till 2030. (2013). Retrieved December 26, 2013, from http://www.opzt.ru/_files/3003.docx

Drozdova, I. I. (2014). Import substitution as one of the factors of economic security of industrial enterprises in the sphere of railway transport in conditions of WTO. World applied sciences journal, 29(8), 1000-1003. 
Golubetskaya, N., \& Kalnitsky, I. (2009). Development of the systems of state regulation of investment activity in real sector of Economy with the purpose of transition to innovative way of development. Economy and management, 2(5), 28-33.

Guzik, V. F., Shmoylov, V. I., Lyapuntsova, E. V., \& Kirichenko, G. A. (2014). One of the approaches to the analysis of rapidly oscillating functions. WIT Transactions on Information and Communication Technologies, 58, 405-413. http://dx.doi.org/10.2495/ICTE130501

How Russia's accession to WTO influences Altai economy? (2013). Retrieved December 26, 2013, from http://www.altkprf.ru/press-tsentr/analytics.html77000

Ivanov, I. (2012). Import and import substitution in Russia. World economy and international relations, 1, 21.

Obolensky, V. P. (2010). Technological modernization of industry: Import contribution. Russian External economical Journal, 3, 37.

World and regional export profiles. (2012). Retrieved December 26, 2013, from http://www.wto.org/english/res_e/statis_e/world_region_export_12_e.pdf

World Bank Report. (2013). Retrieved December 26, 2013, from www.worldbank.org/ru/news/press-release/2013/12/14/world-bank-revises-its-2013-growth-projection-for-r ussia

World Bank. (2013). Structural challenges to growth become binding. Russian economic report: No. 30. Washington DC; World Bank. Retrieved December 26, 2013, from http://www.documents.worldbank.org/curated/en/2013/09/18381827/structural-challenges-growth-binding

WTO Public Forum. (2012). Is Multilateralism in Crisis? Retrieved December 26, 2013, from http://www.wto.org/english/forums_e/public_forum12_e/public_forum12_e.htm

WTO Public Forum. (2013). Expanding Trade through Innovation and the Digital Economy. Geneva, WTO headquarters. $\quad$ Retrieved December 26, 2013, from http://www.wto.org/english/forums_e/public_forum13_e/public_forum13_e.htm

\section{Copyrights}

Copyright for this article is retained by the author(s), with first publication rights granted to the journal. This is an open-access article distributed under the terms and conditions of the Creative Commons Attribution license (http://creativecommons.org/licenses/by/3.0/). 